\title{
KERK EN CHRISTENDOM EN DIE VOLKERELEWE
}

IN AFRIKA

\section{Religie en volk}

In die studie van die lewe van sg. primitiewe volke is dit treffend watter intieme verband daar bestaan tussen ' $n$ volk se religie en sy sosiaal-politieke struktuur. In laaste instansie berus die gesag van regeerder en regering bv. op die religieuse sanksie. Die verskynsel van "goddelike konings" en van priesterkonings is wyd bekend. In Afrika dien die Egiptiese farao's seker as die beste voorbeeld hiervan terwyl oorblyfsels daarvan aanwesig is in die politieke stelsels van verskeie Afrikavolke. By die Bantoe vervul die stam- of volkshoof ook 'n religieus-rituele rol. Dit is een van die hoekstene van sy saamgestelde amp en van sy essensiële funksies. En juis daar waar feitlik geen duidelike politieke struktuur aan te wys is nie weens die afwesigheid van politieke funksionarisse, administratiewe amptenare en regsplegers, is dit, naas die verwantskapsfaktor, juis die religieuse opvattinge en sanksies wat verantwoordelik is vir die handhawing van orde. Selfs die verwantskapseenheid funksioneer deur sy geworteldheid in die geloof in die bestaan en optrede van die voorouergeeste.

Onder die Afrikavolke kom dit betreklik algemeen voor dat 'n volk se ontstaan tesame met sy besondere kultuurpatroon regstreeks aan die oerskeppingsdaad van sy opperwese gedank word. By enkeles soos die Kede (Noord-Nigerië) en die Hima-Iru van Ankole (Uganda) is hierdie mitologiese fundering van die volksbestaan aan 'n spesifieke goddelike daad besonder prominent en word die voortbestaan selfs afhanklik gestel van 'n bepaalde ritueel-religieuse simbool (die Bagyendanwa-drom van die Hima-Iru of die jaarlikse drieërlei Ndaduna-, Ketsa en Tsoede-ritueel van die Kede).

Die verband bestaan nie net tussen die religie en die politieke komponent van die volkskultuur nie. Die religie en kultuur in sy volle omvang is so erg verstrengel dat dit haas onmoontlik is om die twee altyd te onderskei om nie eers te praat van te skei nie. Die geloof ten opsigte van die bestaan van die voorouers het nie net 'n religieuse aspek nie maar lê ten grondslag aan verskeie aspekte van die breëre volkslewe: binding van die verwantegroep, ekonomiese verpligtinge en gedragsbeheer. Selfs die beeskraal van die Zoeloe bv. 
vervul benewens prakties-ekonomiese baie belangrike ritueelreligieuse en sosiaal-seremoniële funksies. Omdat elke kultuurpatroon op 'n bepaalde waardestelsel berus (Benedict: konfigurasie) en lg. weer wortel in die religieuse premisse, bewys die studie van kultuurverandering hoe intiem verandering van die kulturele verbonde is aan die prysgawe van religieuse oortuigings.

Hierdie noue verband tussen die religieuse en die nasionaal-kulturele is nie beperk tot die heidendom nie. Die feit dat die Joodse volk 'n besondere roeping moes naleef, maak nòg die feit, nòg die prinsipe ongeldig. Juis in hierdie uitsonderlike lê opgesluit die normale, wat nie deur die sonde aangetas is nie, vir ons in 'n gebroke bedeling, juis die ideale van nouste ineengeweefdheid van religie en volksbestaan. Religie en kultuur is, in die volk, twee aspekte van die diens van God. Daarin moet dus seker nie gelees word dat wat vir Israel moes geld, vreemd moes wees vir die algemene volkerelewe nie maar dat dit juis die doel moes wees. Later sou die Joodse volk hierin die algemeen sondig-menslike trekke openbaar deur selfs hulle (religieuse) Messiasverwagting aards-tydelik politiek te vertolk.

Die eerste Christene het hierdie verband blykbaar minder bewustelik beleef waarskynlik veral vanweë die teenstand van die kant van Jood en Romein teen die Christendom. Nadat keiser Konstantyn tot die Christendom oorgegaan het, het die houding van die Christene verander. Staat en kerk raak sodanig versoen dat die verhouding tussen die twee instellinge toenemend intiemer word en later uitloop op 'n feitlike vereenselwiging van wêreldlike met kerklike heerskappy. Die stryd tussen pous en keiser was nie soveel 'n ontkenning van hierdie opvatting nie maar eerder die gevolg van persoonlike ambisies verbonde aan die strewe na mag. Onderliggend daaraan was die opvatting dat in die Roomse Kerk die volkereverskeidenheid opgelos word onder die politiek-kerklike pouslike gesag. Die universele kerktaal, Latyn, was een dienstige middel soos die een hoofstad, Rome.

Afgesien van die verhouding staat-kerk moet tog ook met dankbaarheid kennis geneem word van die kerstening van die volkerelewe binne die kader van die "heilige Romeinse ryk" gedurende die Middeleeue. Weliswaar het veel van die Europese heidendom - Grieks, Romeins, Germaans, Kelties e.a. - ook die Christendom binnegedring en behoue gebly en 
'n enigsins sinkretistiese resultaat gelewer. Tog het Europa na die Middeleeuse inkubasietyd met 'n grootliks Chrisielikgeoriënteerde lewens- en kultuui patroon na vore gekom. Op hierdie breë gekerstende beskawingsagtergrond sou die Her vorming verder suiwerend inwerk en met groter geleentheid aan die volkseie.

Luther het nie so radikaal met die Roomse gebreek as Calvyn nie en toon minder duidelik ' $n$ begrip van die verband tussen Christendom en volk, kerk en volk, kerk en staat. Tog toon sy opvatting van die volkskerk aan hoe eng Luther hierdie verband gesien het. Calvyn $\mathrm{k} u \mathrm{~m}$ tot 'n ander uitspraak. Die soewereiniteit van God geld op alle gebiede, ook op die volkse. Die soewereiniteit handhaaf egter die veelvormigheid. Op hierdie fondament word die Calvinisme die groot bevryder van die volke sowel uit politieke onderdrukking as uit saamsmelting in één kerk. Daarom kan Kuyper tereg sê dat die Calvinisme 'n eie vorm aan die lewe en denke gegee het onder die volke van Wes-Europa, Noord-Amerika en Suid-Afrika.

Die Protestant aanvaar dat die Christendom betekenis het vir die volkerelewe. Hier geld egter 'n ander uitgangspunt as dié van die Roomse. Daarom eis of verwag hy nie die opheffing van die volke en die volkeverskeidenheid nie maar die heiliging daarvan. Die volke verdwyn in hierdie bedeling nie in die koninkryk van die hemele nie maar die koninkryk kom in die volke. Die Nederlandse Geloofsbelydenis stel die verband in art. 36 deur formulering van die taak van die owerheid, en Kuyper gee daaraan uitdrukking in sy leer van die soewereiniteit in eie kring: volk en kerk is nie dieselfde nie maar nie daarom sonder verband nie. Daarom aanvaar die Calvinisme nie die gedagte van 'n volkskerk of van 'n staatskerk nie maar van 'n kerk onder ' $n$ volk en organisatories binne die grense van 'n bepaalde staat en tog ook weer uitstrekkend oor volke en staatsgrense heen.

\section{Christendom en die Afrikavolke}

Vir die huidige gebeure in Afrika is dit nodig om in ag te neem dat die Christendom en die Westerse politieke indringing, alhoewel nie heeltemal gelyktydig nie, in verband met mekaar hierdie vasteland binnegekom het. Portugese, Engelse, Franse, Nederlanders e.a. uit Europa het aan die een kant Afrika politiek onderwerp en andersyds sendelinge gelewer 
om die evangelie van Christus hierheen te bring. Vir Alrika was dit die Witman se religie. Vir die volke van hierdie vasteland - veral vir dié wat nog nie met die Islam kennis gemaak het nie - was daar baie bevreemdende aspekte aan hierdie religie verbonde. Verwarrend was die verskille onder die Christene: Roomse, Lutherse, Calvinistiese, Metodistiese, e.d.m. Mense van dieselfde volk het tog dieselfde geloof? Verwarrend ook was die verskil tussen die boodskap van die sendelinge en die lewenspraktyk van ander "Christene". Groot teenstand is gebied teenoor die Christendom se verwerping van die voorouerverering en alles wat hiermee in verband staan. Ondersoekers vind dit nog gedurig dat mans uit die Afrikavolke minder geneë is om lidmate van die kerke te word as vroue. Pauw se verklaring is dat die Bantoeman se religieus-sosiale rituele verpligtinge dit vir hom baie moeilik maak om Christen te word: ook sy sosiale prestige en posisie word deur die oorgang geraak. Hoofmanne word hierdeur nog ernstiger getref.

Reaksies hierop is veelseggend. Waar die Herero tradisioneel by die dood van 'n stamlid die knoop uit die riem gehaal het wat gemaak is by geboorte, word dit nou ook gedoen wanneer 'n stamlid Christen word. Van die Ashanti word gesê: „Christianity comes into immediate conflict with the chiefs in Ashanti... Native converts cut themselves so completely adrift from the rest of the community that the chiefs are afraid to encourage a movement that experience tells them will, in course of time, undermine their power" (Busia, bl. 133).

Die reaksie was nie altyd so uitgesproke negatief en skerp nie, maar ook baie selde onvermengd positief. Veelal was dit 'n ontvangs met gemengde bejeëning. In die vroeëre tydvak toe dit byna mode was om die blanke se lewenswyse na te volg in die strewe na beskaafdheid (vgl. vorige referaat) is die Christendom wel omhels, indien nie as religie nie dan wel as beskawingsfaktor of -kanaal. Oor die algemeen was dit veral vroue wat anhangers van die kerke geword het, aangesien dit aan hulle nuwe status en lewensruimte geskenk het (Brandel-Syrier). Maar selfs hierdie aanvaarding deur die vroue kan onder die mans 'n element van verset wakker roep aangesien dit daartoe geneig het om die tradisionele verhoudinge te versteur en die gevestigde belange van die mans te ondermyn.

'n Ander belangrike vorm van aanvaarding was dié wat tot uiting gekom het in die separatistiese sektes of onafhank- 
like Bantoekerke met hulle sterk akkulturatiewe elemente van nasionaal-religieuse Afrikatradisies binne die nuwe reiigieuse vorm, nl. die kerk. Sundkler se studie (Bantu Prophets) beklemtoon hierin o.a. die sterk voortlewing van die Zoeloe se politieke leierstradisie in die leiersfiguur van die Zionistiese amaNazaretha-kerk van Shembe. Dieselfde is merkbaar in Lekganyane se Zion Christian Church en in ander van hierdie kerke. Dieselfde geld (ten opsigte van die Zoeloes) o.a. die assosiasie tussen Heilige Gees en die voorouergeeste, Kersfees met die Umkhozi of fees van dic eerste vrugte e.d.m.

Ten nouste verwant hieraan en dikwels voortspruitend uit die separatistiese groepe is die Messiaanse of profetiese bewegings. Die koloniale geskiedenis van Afrika is vol van hierdie bewegings waarin religieuse en politieke doelstellinge ineenvloei: dit geld die animistiese heidendom sowel as die Islam.

Dit was die lotgeval van die Wagtoring-beweging in NoordRhodesië in die twintigerjare. $\mathrm{Lg}$. het noue verband gehad met die Chilembwe-opstand in Njassaland in 1915 toe die Amerikaans-opgeleide John Chilembwe sy eie sekte gevorm en sy volgelinge op verskeie plantasies tot opstand en moord op die eienaars georganiseer het. Hy het self met 'n vermoorde landgoedeienaar se kop op sy kansel 'n preek gelewer. In Uganda het die Malata-sekte, naas ander meesal heidense praktyke soos poligamie, hulle verset teen die inenting van vee teen runderpes. Frans-Wes-Afrika het sy Harris-beweging beleef waarin die Franse administrasie waarskynlik meer politiek vermoed het as wat werklik daarin aanwesig was. Dic beweging van Simon Kimbangu in die Kongo was waarskynlik sterker politiek gekleurd, maar of die Belgiese administrasie se optrede geregverdig was is 'n ander saak. Suid-Afrika het in 1921 die ervaring met die "Israeliete" van Bulhoek (naby Queenstoun) beleef toe hierdie sekte hulle verset het oor woonregulasies, die kerkterrein tot 'n kaserne omskep en die volgelinge in 'n leër georganiseer het. Een van die bekendste politieke ontwikkelinge van 'n eertydse religieuse beweging in Afrika is die Mau-Mau, wat sy wortels waarskynlik gehad het in die vroeëre profetiese bewegings soos die watu wa Roho (mense van die Heilige Gees), die watu wa Mungu (velmense) en Dini ya Misambwa (kulte van die goeie geeste)

Die groeiende politieke ontwaking en die toenemende nasionale besef het hom in Afrika, soos oral ter wêreld duars- 
deur die geskiedenis, primêr kenbaar gemaak in 'n afwysende en vyandige houding teenoor die heersersvolk. Deur die assosiasie van blankedom en Christendom in Afrika het die verskynsel hom nie onbetuigd gelaat ten opsigte van laasgenoemde nie. Veral die ekstremiste wou die kind met die badwater uitgooi. Trouens, ook die flirtasie met die Kommunistiese state en met Islam-volke het dit vir die leiers van Afrikavolke nie maklik gemaak om liefde vir die Christendom te bely nie. Tog beroep verskillende van die politieke leiers hulle op hulle opleiding aan ' $n$ sendingskool en hulle verband met ' $n$ spesifieke cienominasie sonder dat veel daarvan te sien is in hulle politieke optrede.

'n Ander belangrike aspek hiervan is die nasionale ontwaking in kulturele sin. Al die verskillende formuleringe en terminologiese skeppinge soos Nkrumahisme, African socialism, Negritude, Neo-African culture, is niks anders as 'n manifestasie van die verlange na die band met die eie tradisie nie. Dit is onafskeidelik deel van die soeke na 'n manifestasie van 'n eie volksbestaan en -identiteit in 'n onderskeibare vorm. Veral vir Suicl-Afrika, en vir kritiseerders van sy beleid, behoort dit besonder interessant sowel as leersaam te wees om kennis te neem van hierdie sterk "nativism”, soos Krocber dit noem: die herlewing van 'n volk se kulturele tradisie. Op politieke gebied kom die behoefte tot uiting in die Afrikanasionalisme en 'n Pan-Afrikanisme. Selfs in die kerklike lewe tree dit op die voorgrond in die verskynsel en problematiek van ,indigenization", verinheemsing van die Christelike kerk onder die Afrikavolke. Op die algemeen maatskaplik-kulturele vlak het dieselfde strewe miskien nog tot minder mate in 'n slagspreuk of organisasie gestalte aangeneem, maar in die letterkunde, ontspanning, politieke party, e.d.m. is die voorlopers onmiskenbaar.

Baie, uit Christelike en nie-Christelike kringe, begin om die nasionalisme in Afrika aan te merk as die wesentlike bron van gevaar vir die algemene politieke vrede sowel as vir die bestaan van die kerk en van die Christendom. Hulle remedie daarvoor is die verdoeming van en stryd teen nasionalisme en die verwerping van volksverskille en nasionale differensiasie. Meer as ' $n$ geveg teen windmeulens kan dit eintlik nie wees nie. Die diagnose is eensydig en gevolglik is die terapie ondoeltreffend, selfs gevaarlik. Die fout lê nie by nasionalisme nie maar by sondige nasionalisme, by chauvinis- 
me. Hierdie houding is veral sterk en opmerklik onder 'n groep blankes en die intellektuele leiers van die Bantoes in Suid-Afrika sowel as by feitlik alle kritici van die SuidAfrikaanse beleid. Hulle standpunt word daardeur gekenmerk dat die woord nasionaal geskrap moet word uit die Afrikaanse standpunt-formulering van Christelik-nasionaal. Afgesien daarvan clat hierdie mense uit voeling is met die res van Afrika, soos terstond aangedui sal word, is hulle houding ambivalent. Eintlik wil hulle, blykbaar onbewustelik, 'n eksklusiewe Afrikaner-nasionalisme vervang deur 'n inklusiewe „African nationalism" sonder inagneming van die vernietigende gevolg daarvan vir die Afrikaner. Psigologies gesien is dit 'n geval van 'n geïnhibeerde strewe na aanvaarding in die SuidAfrikaanse nasionalisme, terwyl hulle openlik alle nasionalisme veroordeel.

Elders in Afrika aanvaar Christene die onvermydelike werklikheid van die volkskap en van sy uitdrukking in nasionalisme. Weinig ondersoeke werp duideliker lig hierop as een wat, opmerklik genoeg, onderneem is deur die Wêreldraad van Kerke en wat in samewerking met die All Africa Church Conference gepubliseer is onder die titel Africa in Transition. Vanweë die bron waaruit dit kom sowel as op grond van die inhoud van die rapport word in die volgende paragrawe dikwels hierna verwys.

Vergelyk die volgende (bl. 15): „In every country of Africa ... one problem pre-occupies the minds of the people, that of nationbuilding. All Africans... are united in their effort... to free themselves from... Western colonialism. This is the substance of what is commonly called African Nationalism. It is also the dynamic underlying the movement of Pan-Africanism... What is crucial is that African people in a given geographical area and of more or less common cultural heritage ... shall form a nation they call their own. What is sought is a national self-identity..."

Dit is die onloënbare feit van nasionalisme in Afrika. Die verdere aanhalings en verwysings toon aan dat baie Christene van Afrika oortuig is dat hulle hierby betrokke is, en tweedens wat hulle meen hulle betrokkenheid konkreet beteken. „Christian Africans are frequently caught in the profoundly disturbing situation of having to live in countries where nationalism is the motivating force of the people, yet which are still under colonial rulers, who are often unable to see the reality of the 
new Africa. They ask what their Christian responsibility is in this agonizing stage of 'birth pains'". Dr. Bebey-Eyida se oortuiging is dat "the Christian Church has a role of the first importance to play and heavy responsibilities to assume" in hierdie beweging ter bevryding van die koloniale juk. „Treading a path between the will to survival of the past and the attraction of a dynamic communism, the Church must find a satisfactory formula which will allow the African countries to achievo the sovereignity they desire, even while remaining Christian. Recently freed from the guardianship of the mother country, the autonomous churches and their leaders will not be able to remain neutral before the national problem. They are obligated to take a clear position and to contribute to the country's political liberation, without which ecclesiastical independence cannot be fully assured. It will be by taking up anew the nationalist cause, by helping the nationalists in the political struggle, by pursuing and multiplying their achievements in the social and educational spheres that the young African churches will consolidate their position and assure their future survival".

Die oortuiging is dat die Christene nie meer afsydig kan staan nie. „African Christians in such an atmosphere are growing impatient with socalled non-partisanship in politics or political neutrality of Protestant churches and missions". Die Rooms-Katolieke Biskoppe van Madagaskar se verklaring van 1953 is onderskryf deur Protestante. „We recognise the legitimacy of aspirations to independence as well as all efforts being made to achieve it. The church earnestly desires that individuals as well as peoples shall assume ever more fully their responsibilities..." Uit die Kameroen word dit só gestel: "Some of our compatriots withdraw into an ivory tower of false neutrality, which in reality is nothing but fear of responsibilities, and declare... I will have nothing to do with politics! What hypocrasy! They are involving themselves in politics by the very fact that they take a political position when they say they will have nothing to do with politics..."

Uit Ghana kom dieselfde stem: "the Christian has the responsibility to be politically involved". Die Ghanese Christenburger moet skeppend dink oor die regering van sy land ,and bring our own Christian conscience to bear on them. As an indigenous Church we must bring to our own Government and public bodies the challenge and stimulus of a Christian social 
conscience that arises out of our own knowledge of Christ and experience of the guidance of His Spirit in regard to the social needs and problems of this country".

\section{Probleme en vitdaging}

In die atmosfeer van opstuwende ,bigoted form of nationalism" is dit bepaald nie altyd maklik vir die Christen om sy plek te vind in sy volkstruktuur en om sy taak te volvoer nie. Sy bestaan word nie net genegeer nie; intimidasie van en diskriminasie teen Christene kom veelvuldig voor. In gebiede soos die Soedan span die Arabies-Islamse nasionaal-religieuse komponente selfs saam in 'n vervolging van Neger- en BantoeChristene. Die dikwels nog swak Christen word in gevalle soos Angola, Mosambiek en die Kongo gekonfronteer met die baie aktuele vraag van sy houding teenoor deelname aan gewelddadige bevrydingsbewegings en rebelle-optrede. Dit is ' $n$ verskeurende keuse: tussen die volksgevoel en die Christelike leerstellings van liefde en geweldloosheid. 'n Ander moeilikheid wat ook na vore gebring word is die verwagtinge wat aan die kerk gestel word betreffende die probleme wat deur die tradisionele lewenswyses en deur die veranderde sosiaal-ekonomiese omstandighede gestel word.

Dieselfde verslag wys nog verder op ander soortgelyke kwessies. „How can we create a meaningful sense of nationalism and at the same time face the demands of the twentieth century for international co-operation?" (bl. 20). Hiermee word die moeilike vraag vir die Afrikavolke gepostuleer hoe hulle pasverkreë vryheid en hartstogtelik gekoesterde nasionale bestaan versoen moet en kan word met die gangbare wêreldmening - wat hom beroep op Christelike leerstellinge: die volkegemeenskap moet plek maak vir 'n wêreldsamelewing, nasionalisme vir kosmopolitisme. Dieselfde probleem is natuurlik reeds begrepe in die Pan-Afrikanistiese eenheidsdroom van leiers soos dr. Nkrumah en die verlange van die individuele volke om as sodanig voort te bestaan. Die Christendom sal hierop 'n duidelike antwoord moet gee.

Die Christene is nie onbewus van die probleme waarmee hulle op hierdie weg te doen sal kry nie. "It is not always easy for Christians who are responsibly involved in politics to maintain their ethical integrity, and it is the responsibility of the Church to give them understanding support" (bl. 23). 
En: „It is dangerous give them our young Christians into the turmoil of politics without giving them the necessary guidance. They will discover for instance that party politics in Central Africa is bedevilled by the idolatry of the 'Personal Cult'. The standard we must give our Christians is this: not who is right, but what is right".

Dit is dus duidelik dat die Christianisering van die nasionale politiek in Afrika 'n veeleisende taak sal wees. 'n Christelike politieke program is waarskynlik nog nêrens geformuleer nie en Christelike politieke partye bestaan feitlik nie. Die kans om in hierdie rigting te ontwikkel word al geringer namate die eenparty-stelsel al meer aanhang verwerf. Hier sou die Christendom 'n rol te speel hê indien hy oor genoeg dinamiese en onderlegde leiers kan beskik en indien die volksgemeenskap wat die basis van 'n demokratiese politieke verteenwoordiging vorm, in genoegsame omvang en mate self ook verchristelik was. Albei die voorwaardes is maar uiters beperk aanwesig. Die bydrae van die Gereformeerde kerkregeringstelsel vir 'n ware en verantwoordelike stelsel van volksregering is nie berekenbaar nie. Maar ook hier moet nou nog erken word dat die meeste kerke in Afrika onder meer hierargiese kerkregeringstelsels handhaaf. Sundkler bevind bv. dat die Bantoetradisie van 'n rangordelike regering die demokratiese grondslae van die Metodistiese kerkregering ombuig tot 'n hierargie.

Waar die skool vroeër as sendingskool 'n belangrike kanaal was om die Christelike leerstellinge en lewenspraktyke in die volkslewe in te dra - hoe gering in omvang miskien ook al - gaan die inisiatief hier merendeels uit die hande van die Christene deurdat die nuwe state, hetsy uit eie middele hetsy met hulp van buite, onderwys as 'n staatsonderneming in hande neem. Selfs hierby is die nie- en antiChristelike magte in die meerderheid: tradisionele heidendom, Islam, hulp uit die kommunistiese en sosialistiese kampe of uit die demokratiese V.S.A., waar godsdiens in die skool tans taboe is. Die gevolg hiervan is tweërlei. Daar word nie 'n Christelik-georiënteerde volksmassa gevorm nie en daar word nie Christenleiers gekweek nie. „The newly emergent nations lack the competent leadership to cope with the gigantic task of nation-building". Op 'n konferensie van ongeveer 130 Christenleiers uit Afrika te Salisbury, Des. 1962-Jan. 1963, is gepoog om 'n antwoord te vind op dié vraag: „We know' that 
Western education was brought to Africa by the Christian Churches, and the Churches are still carrying a great part of the load. But now the African Governments have said that with Unesco's help they hope to have all their children in primary schools by 1980 , and a great many more children in secondary schools. What then should be the work of the Churches in this new situation?" (A.A.C.C. Bull, bl. 49).

Saam met die blanke het 'n nuwe arbeidspraktyk en -geroonte Afrika binnegekom en deel geword van die kultuur van die volke van Afrika. Die strewe van die nuwe, vrye Afrikastate na ekonomiese ontwikkeling en industrialisering bevestig dit verder as komponent van die toekoms. Na beeindiging van die slawestadium en met die begin van nywerheidsontwikkeling op die vasteland het die Trade Union-beweging as model van arbeidersorganisasies gedien. Intussen het die arbeid oral 'n belangrike indringingsterrein geword van sosialistiese en van selfs nog sterker linkse opvattinge en optrede. Met dankbaarheid kan egter gekonstateer word dat Christelike arbeidersorganisasies ook ontstaan het. Oor die algemeen is hulle nog swak en nie genoegsaam gekoördineer nie terwyl opgevoede leiers sterk in aanvraag is.

Op maatskaplik-kulturele gebied het veel van die ou instellinge en opvattinge nog ' $n$ uiters sterk houvas. Poligamie word waarskynlik meer deur sosio-ekonomiese faktore aan bande gelê as wat dit afgewys word op grond van Christelike oortuigings. Dit is opmerklik hoe dikwels sg. Christelike sektes juis hierdie kulturele komponent 'n prominente plek in hulle belydenis en lewenspraktyk gee. Harris bv. (Buell II, 67) het nieteenstaande die origens sterk sedelike strekking van sy prediking poligamie verdra. Die Malaki-sekte van Uganda het dit eksplisiet bepleit. Volgens Sundkler lei dit selfs tot kerkskeuring tussen voor- en teenstanders. Ander instellinge wat swaar sterf is die inisiasie. Daar bestaan nog baie verskil van mening oor die vraag of dit afgew'ys of verchristelik moet word. Ook die houvas van die magiese lewensbeskouing is nog geensins deurbreek nie. Dit kom na die oppervlak in baie vorme: die medisyne van en behandeling deur 'n toordokter eerder as deur 'n gekwalifiseerde geneesheer; die toevlug tot towermedisyne ter bestryding van natuurrampe soos peste en droogtes. Die neem van menselewens ten einde die noodsaaklike bestanddele te verkry kom, blykens polisie-ondersoeke en hofsake, nog steeds voor nieteenstaande die verbie- 
dende wette. Divinasie (waarsêery) word grootskaals beoefen saam met die gebruik van talle towermiddels. En onder alles bly die voorouergeeste sells onder verstedelikte Bantoes en ander Afrikane dikwels nog die hoogste toevlugsoord.

By hierdie struikelblokke uit die tradisionele kultuur moet die sosiale, ekonomiese en kulturele veranderinge wat die Westerse tegniek en beskawing onder die Afrikane teweeg gebring het, nog bygevoeg word. Ook daarvoor bestaan veelal nie 'n Christelike antwoord, altans 'n vir hulle bekende en aanvaarbare antwoord, nie. Die sprekendste voorbeeld in hierdie verband geld waarskynlik die seksuele lewe. Alhoewel die kuisheidsopvattinge van hierdie volke eintlik daarop neergekom het dat 'n ongetroude dogter nie moeder mag word nie, is voorhuwelikse en buitehuwelikse omgang oor die algemeen sterk afgekeur. Onder die nuwe omstandighede het die remminge van familiebeheer en -toesig deur ouderdomsgroepe begin faal. Omvangrike onkuisheid gaan nou gepaard met eweveel ongetroude vader- en moederskap met verreikende gevolge vir die verwantskapsisteem en nog meer vir die opgroeiende generasies.

Afrika het nog nie die geleentheid geniet om 'n Christelike inkubasietyd te beleef nie. Daarvoor ontbreck dit aan twee voorwaardes: 'n sterk oorheersende en verenigde Christendom en 'n tyd van isolasie. Op die tweede is klaarblyklik nie te hoop nie: die $20 \mathrm{e}$ ecu, en sekerlik ook die daaropvolgende, is nie tye vir hermetiese afsondering en stilte nie. Inteendeel, Afrika het nouliks ontwaak of sy nuwe volke en state is met verbluffende haas en gevolglike verwarring betrek in elke internasionale aktiwiteit en instelling. Daarby begin Afrika sy nuwe era nie onder leiding van 'n magtige kerklike instituut nie. Die Christendom in Afrika is, na die mens gereken, swak en verdeeld. Dit is veelal, uit ons standpunt beskou, ver weg van die Skrif af. Die belydenisse en kerke wat die duidelikste in lyn lê met die Hervorming is die swakste verteenwoordig. Daar kan alleen gekonstateer word dat nieteenstaande hierdie swakhede, 'n sterk begeerte na die Skrif in sy onverminderde gesag en in sy onvervalste inhoud te bespeur val.

Vir die kerstening van die volkerelewe in Afrika wag daar nog 'n groot veld en 'n dringende taak. Dit is nodig om aanknopingspunte in die kultuur van elke volk te vind en om wat nie gekersten kan word nie, uit te suiwer. Want dit 
is die wese van die Christelik-nasionale: dat die nasionale na die Crristelike eise omgevorm moet word. Wesenlik is dit 'n vernuwing: ou instellinge moet Christelik deurdring en nuwes moet geskep word. Die omvang van die taak beklemtoon die noodsaaklikheid enersyds van koördinasie van Christelike kragte en andersyds van die suiwerheid van belydenis en Christelike kennis. Christelike hulp is nie oorheersende paternalisme nie maar broederlike toesig en advies. Die Westerse Christendom het nie die hele en volle antwoord op al dic vrae van die volks- en kultuurvernuwing van Afrika nie. Maar hy het die basiese kennis: die Skrif, belydenis, denke en ervaring. Die eerste aansluiting van die Gereformeerde Christendom met die nuwe Afrika is die erkenning van die volkereverskeidenheid. Verder kan dit mededeling doen van sy ervaring en kan hy skatte wat in sy geskiedenis uitgekristalliseer het, aanbied. Maar dit is die Afrikaan self wat daaraan sy nasionale en volksvorm moet gee.

P.U. vir C.H.O.

J. H. Coetzee.

25 Augustus 1965.

\section{ENKELE BRONNE:}

All African Church Conference: Africa in Transition. 1962. Bulletin. October 1963.

Bascom and Herskovits: Continuity and Change in African Cultures. Chicago. 1963

Buell, R. L.: The Native Problem in Africa. New York. 1928.

Busia, K. A.: The Position of the Chief in the modern political System of Ashanti. London. 1951.

Farson, N.: Last Change in Africa. London. 1951.

Hodgkin, T.: African Political Parties. London. 1961.

Holl, K.: The Cuitural Significance of the Reformation.

Jahn, J. H.: Muntu. London. 1961.

Kuyper, A.: Het Calvinisme. Kampen. 1959.

Pauw, B. A.: Religion in a Tswana Chiefdom. London. 1960.

Schlosser, K.: Eingeborenenkirchen in Süd- und Südwest-Afrika. Kiel. 1958.

Southall, A.: Social Change in Modern Africa. London. 1961.

Sundkler, B. G. M.: Bantu Prophets in South Africa. London. 1961. 